\title{
Аналіз торакоскопічних втручань у хворих на спонтанний пневмоторакс
}

\author{
A. D. BEDENIUK, V. V. MALIOVANYI, I. Z. HUMENNYI, S. I. DUTS, A. YE. BURAK \\ I. Horbachevsky Ternopil State Medical University
}

\section{ANALYSIS OF TORACOSCOPIC INTERVENTIONS IN PATIENTS WITH SPONTANEOUS PNEUMOTORAX}

Аналізуючи сучасну літературу, можемо стверджувати про зростання бульозної емфіземи легень, ускладненої спонтанним пневмотораксом (СП). Дана патологія виникає переважно в молодих працездатних чоловіків. Причиною спонтанного пневмотораксу в 97,5 \% випадків є бульозна емфізема легень. У значній більшості випадків дана патологія має рецидивний характер і складає 35-75 \%. Лише хірургічне лікування дозволяє усунути причину пневмотораксу та ліквідувати рецидивування ускладнення. Тому загальноприйнятою тактикою лікування в 96 \% випадків $\epsilon$ атипова або сегментарна резекція легені в зоні бульозної емфіземи. Невеликий об'єм хірургічного втручання вимагає травматичного доступу. У зв'язку з цим малоінвазивні хірургічні втручання стають надзвичайно актуальними.

Метою роботи було вивчення переваги торакоскопічних втручань у хворих на бульозну емфізему легень, ускладнену спонтанним пневмотораксом.

Проведено аналіз лікування хворих на бульозну емфізему легень, ускладнену спонтанним пневмотораксом, які перебували на лікуванні у відділенні малоінвазивної хірургії КЗ ТОР “Тернопільська університетська лікарня” за період 2013-2015 рр. Пацієнтам виконано 120 торакоскопічних досліджень, серед яких було 118 чоловіків та 2 жінки у віці 18-60 років, що, в свою чергу, дозволило виявити причину спонтанного пневмотораксу. В 78 випадках (77 чоловіків та 1 жінка) усунення причини СП проводили малоінвазивним способом. В 71 випадку причиною СП послужила бульозна емфізема легень, що ускладнилась розривом субплевральної кісти та формуванням альвеолярної нориці. У 7 випадких виявлено дефект вісцеральної плеври з формуванням альвеолярної нориці на фоні відриву легеневої шварти.
У 37 випадках проведено атипову сегментарну резекцію легені за допомогою прямого ушиваючого апарата ECHELON 60. Це дало можливість здійснити двобічне прошивання легеневої тканини з одночасним її пересіченням. У 30 хворих герметизацію нориці проводили за допомогою танталових кліпсів фірми Sztorz розміром 8 мм, і в 11 випадках у зв'язку з відсутністю надходження повітря проводили діатермокоагуляцію бул. Герметичність легеневої тканини в місці резекції перевіряли шляхом введення розчину “Декасан” та гіперпресією при штучній вентиляції легень. Розчин антисептика аспірували і плевральну порожнину дренували поліхлорвініловими трубками 3 підведенням їх в апертуру та френікокостальний синус під контролем торакоскопа. Дренажі видаляли з плевральної порожнини на 1-3 добу післяопераційного періоду при розправленні легені та припиненні плевральної ексудації.

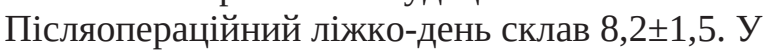
групі хворих з використанням торакотомії цей показник склав $12 \pm 2,2$.

Висновки. 1. Спонтанний пневмоторакс є підставою для госпіталізації хворих у відділення торакальної або малоінвазивної хірургії для ранньої діагностики та лікування.

2. Торакоскопічна діагностика показана всім хворим із первинним та рецидивним спонтанним пневмотораксом.

3. Операція дозволяє виявити причину пневмотораксу та усунути ї̈ хірургічним шляхом: ушивання альвеолярної нориці або резекція бульозно зміненої легені.

4. Спостерігали зниження післяопераційного періоду до 8,2 $\pm 1,5$.

5. Проведення хірургічного лікування малоінвазивним шляхом, на відміну від відкритої операції, дає значний косметичний ефект. 